Published as: Schoonbeek, S., Azadi, H., Mahmoudi, H., Derudder, B., De Maeyer, P. \& Witlox, F. (2013): Organic Agriculture and Undernourishment in Developing Countries: Main Potentials and Challenges. Critical Reviews in Food Science and Nutrition, 53(9): 917-928.

\title{
Organic Agriculture and Undernourishment in Developing Countries: Main Potentials and Challenges
}

\author{
Sanne Schoonbeek ${ }^{\mathrm{a}}$, Hossein Azadi ${ }^{\mathrm{b} 1}$, Hossein Mahmoudi ${ }^{\mathrm{c}}$, Ben Derudder ${ }^{\mathrm{b}}$, Philippe De Maeyer ${ }^{\mathrm{b}}$, Frank Witlox ${ }^{\mathrm{b}}$ \\ ${ }^{a}$ Faculty of Geosciences, University of Utrecht, the Netherlands \\ ${ }^{b}$ Geography Department, Ghent University, Belgium \\ ${ }^{c}$ Department of Social Sciences in Agriculture, University of Hohenheim, Germany
}

\begin{abstract}
While much has been published on the advantages of organic agriculture, less has addressed its potentials and challenges to fight undernourishment in developing countries. This article aims at reviewing the main potentials and challenges of this approach when dealing with "undernourishment" as a multi-faceted concept in developing countries. Accordingly, two main issues of the concept which are "food security" and "food safety" are discussed in the context of both developed and developing countries to understand their different food policies' priorities. Next, the main potentials, challenges and tradeoffs of the organic approach are scrutinized to understand whether the approach is capable to provide a secure or safe food production system and therefore to understand whether it can meet the food policies' priorities in developing countries. With respect to food security, the article concludes that conventional and biotechnological approaches still appear to produce higher yields though considering many advantages of organic agriculture, it could, in long run, be more conducive than now to meet food security. Hence, we still need both conventional and
\end{abstract}

${ }^{1}$ Corresponding author. Email: hossein.azadi@ugent.be, Tel. +32 (0)9 26446 95. Fax +32 (0)9 2644985. 
biotechnological approaches to feed the hungers in developing countries. Accordingly, the article emphasizes on providing farmers in developing countries with the possibility of implementing different approaches. Therefore, policy makers should be aware of a realistic and gradual transition from the other approaches to the organic that should be projected only in "long run", and after conducting a series of risk assessment studies on the bases of both "crop-case" and "region-case".

Keywords: Food security, food safety, food policy, sustainability.

\section{Introduction}

While food security is one of the major issues worldwide, it is a much more serious problem in developing countries. In fact, in many developed countries (e.g. the United States, United Kingdom and Canada), the percentage of people who are obese is extremely large $(33.8 \%$, $24.5 \%$, and $24.2 \%$ respectively) (OECD, 2008). This situation stands in sharp contrast with the conditions in many developing countries where currently 925 million people are suffering from undernourishment (FAO, 2010). However, the lack of food in the world is not the problem. As Amartya Sen (1981: 1) said: "Starvation is the characteristic of some people not having enough food to eat. It is not the characteristic of there not being enough food to eat". Therefore, it is important to understand whether the one who "produces the food, has access to the technology and knowledge to produce it, and has the purchasing power to acquire it" (Pretty et al., 2006: p. 1114). This already points to the importance of food production systems in fighting undernourishment.

One of the food production systems that is rapidly expanding is organic agriculture (OA). The UK organization Organic Monitor already estimated that "the organic food and drink market has grown 235\% from 1999 reaching nearly \$51 billion worldwide by 2008" (Mactaggart, 2010: 7). There are now around 1.5 million organic producers worldwide 
(Mactaggart, 2010) and many of them live in developing countries: a quarter of the 1.5 million organic producers live in India (Mactaggart, 2010). In general, Asia is becoming an important region for organic food production (Willer \& Yussefi, 2007). In this continent, the growth of the organic sector is said to be as high as 30-40\% annually (Kung Wai, 2007). Among Latin American countries that hold $19 \%$ of the world's organic land, Argentina stands at the first, and second (5.8 million hectares of land) in the global ranking (Yussefi \& Willer, 2007). In Africa, the organic sector is still very small: around 900,000 hectares of land are used for organic production of which the most is located in Uganda (around 296,000 hectares). However, in this continent, the sector is also growing (Bouagnimbeck, 2009; Van Elzakker et al., 2007). Moreover, almost half of the world's organic producers can be found in Africa (Willer, 2009). Nevertheless, the producers are mainly smallholders whose contribution to the total organic coverage is not significant. According to Willer (2009: 19) by now, "about one third of the world's organically managed land - almost 11 million hectares - is located in developing countries" (Willer, 2009: 19).

Given this expansion of the organic sector, the important question is to understand how can OA contribute to fighting undernourishment? It is important to note that neither other agricultural approaches (conventional and biotechnological), nor OA can address all the undernourishment causes. In fact, the undernourishment in developing countries is a complex problem as appears differently across the countries and regions (Carvalho, 2006). One can distinguish bio-physical drivers, such as soil degradation (Eswaran et al, 2001); climate change that has direct and indirect influences (Schmidhuber \& Tubiello, 2008) and water scarcity (Falkenmark et al., 1998). Furthermore, there are different kind of socio-economic and political drivers (FAO, 2010; Pingali et al., 2005); poverty (Middleton, 2008; Smith et al., 2000); urban bias in policy making (Jenkins \& Scanlan, 2001); rising food prices (e.g.) as a consequence of the production of biofuels or economic crisis; USDA, 2007); and lack of 
infrastructures (Middleton, 2008; Szirmai, 2005: 391) for undernourishment problem in developing countries. Especially climate change seems to have direct influences on food production (Schmidhuber \& Tubiello, 2008) and land degradation is mentioned as the biggest problem in overcoming hunger in these countries (Sanchez, 2002). None of the causes stand alone but are interrelated in many ways. Also, the causes of undernourishment lie on different regional, national, and international levels (Løvendal \& Knowles, 2005).

This paper is an attempt to analyze what contribution OA can make to fighting undernourishment in developing countries and discusses its main opportunities and challenges. In order to make a thorough analysis, the concept of undernourishment and its multidimensional characters will first be explained. Next, different priorities of food policy in developing and developed countries are discussed. Thereafter, a theoretical debate on OA and its possibility to positively contribute to the different dimensions of undernourishment is presented. This section already points to some main opportunities which are further discussed in line of productivity. Subsequently, the main challenges are presented in a separate section, and finally, a conclusion is drawn on the ability of OA to overcome undernourishment in developing countries.

\section{Undernourishment: a multi-faceted concept}

The term undernourishment, as a multi-faceted concept, needs to be well-defined. FAO (2010: 8) states that undernourishment exists when "caloric intake is below the minimum dietary energy requirement" which is the amount of energy "needed for light activity and to maintain a minimum acceptable weight for attained height". Undernourishment comprises, as the main debates of this paper, of two important concepts: "food security and food safety".

\subsection{Food security}


Food security exists when "all people [of a community], at all times, have physical, social and economic access to sufficient, safe and nutritious food that meets their dietary needs and food preferences for an active and healthy life" (FAO, 2010: 8). Food insecurity then displays when "people do not have adequate physical, social or economic access to food" (FAO, 2010: 8). Such characteristics are now widely understood multidimensional. However, the concept of food security has developed over time (Pinstrup-Andersen, 2009; Mechlem, 2004). In the 60s and 70s, "food production and availability" (physical presence of food), rather than accessibility, were the main concerns. The debate on food security had focused on strengthening food production to increase availability of world food supplies of basic foodstuffs (particularly cereals) to meet the increasing demands of food (Mechlem, 2004: 633). The world food crisis at the beginning of the 70 s and the concern about population growth were the main reasons to focus on the 'availability' dimension (Mechlem, 2004).

However, there was also a focus on the "stability" dimension as food security was defined as the "availability at all times of adequate world food supplies of basic foodstuffs to sustain a steady expansion of food consumption and to offset fluctuations in production and prices" during the UN World Food Conference in 1974 (UN, 1975). This dimension refers to both current and future statuses of food security which is currently appreciated as "sustainable food security". On the contrary, instability may, for example, be caused by rising food prices as a result of population growth and climate change. Also, this dimension is especially important when discussing food insecurity in developing countries as particularly poor people are vulnerable to negative effects of instability of food security. Or as Schmidhuber and Tubiello (2008: 19703) point: "The stability dimensions relates to "individuals who are at high risk of temporarily or permanently losing their access to the resources needed to consume adequate food, either because the individuals cannot ensure ex 
ante against income shocks or they lack enough "reserves" to smooth consumption ex post or both".

The 80s saw a growing awareness of the importance of "access" to food, mainly as a result of Amartya Sen's (1981) emphasis on food entitlements. According to Sen "A foodcentered view tells us rather little about starvation. It does not tell us how starvation can develop even without a decline in food availability. Nor does it tell us -even when starvation is accompanied by a fall in food supply- why some groups have to starve while others could feed themselves" (Sen, 1981: 154). A focus on food entitlement was explaining why some people are undernourished and others are not. The fact that mere food availability is not ensuring food access is mainly demonstrated by the fact that India is a net exporter of food (16 586 million US\$ worth of food export in 2009; WTO, 2009), whereas it is the home of roughly 237.7 million food insecure people (FAO, 2010).

\subsection{Food safety}

By the mid 90s, a new dimension of undernourishment that relates to the concept of food safety and quality was expressed as the "utilization" of food for nourishment (FAO, 2003) "Utilization encompasses all food safety and quality aspects of nutrition; its sub dimensions are therefore related to health, including the sanitary conditions across the entire food chain" (Schmidhuber \& Tubiello, 2008: 19703). Food safety is the assurance that food will not be harmful to consumers when it is prepared and/or eaten according to its intended use (FAO/WHO, 1997). Food quality refers to issues concerning physical characteristics (shape, appearance) and presentations (fresh, preserved); chemical (additives, content); microbiological (use of ferments, presence of germs); organoleptic (flavor, texture, color, sensory profile, aromas, taste) (Vandecandelaere et al., 2009). With respect to the chemical contents of food, the term nutritional security becomes important: "An individual is 
nutritionally secure when he or she has secure access to a nutritionally adequate diet and the food consumed is biologically utilized such that adequate performance is maintained in growth, resisting or recovering from disease, pregnancy, lactation, and physical work" (Smith et al., 2000: 202). Therefore, it is important to investigate the nutritional value of food measured in terms of the levels of (e.g.) proteins, vitamins, and micronutrients. This is important to consider as even more people in developing countries suffer from deficiencies of protein and essential micronutrients, such as iodine, Vitamin A and iron (malnourished people) than there are undernourished people (Smith et al, 2000). Recently, such food safety and quality concerns have gained more and more attention from governments mostly in developed but also in developing countries (Carvalho, 2006; Maitani, 2005; Martin et al., 2003).

\section{Food policies: different priorities in developing and developed countries}

Setting suitable food policies has been one of the major challenges in the world (Lairon, 2010). However, developed and developing countries have different food priorities. On the one hand, developed world has little to fear from hunger (Timmer, 2000). There is even the problem of too much food as obesity is a concern in developed world (OECD, 2008). Looking back at the history of Europe and the US, it appears that even before the First World War (1914-1918), there was a number of examples where availability of food arose beyond market demand and where governments had to step in to secure farmers' income (Shaw, 2007: 12). Furthermore, starting already from the beginning of the 50s, donor countries such as the USA and Canada, started to dispose their agricultural surplus commodities overseas (Gross et al., 2000). With the rise of agribusiness and the 'liberation' and the massive dumping of food surpluses, food dependency of developing countries has dramatically been increased: "the trade balance shifted from a surplus of 1 billion dollar in 1979 to a deficit of 
11 billion dollar in 2001" (Vanhaute, 2009). Nevertheless, the food aid stream is still massive: estimates show that in 2010, the world food program provided developing countries with 3.7 million tons of food (WFP, 2010). The fact that the developed countries can give and dump such large amounts of food already points to their luxury position compared with most developing countries. The concern about food security is therefore not central anymore in developed countries. Instead, the concerns about food safety are growing (Carvalho, 2006). For example, the European Union, USA, Canada (Carvalho, 2006), and Japan (Maitani, 2005) approved new laws restraining the use of agrochemicals, just as Australia has introduced a new national food safety regulations (Martin et al., 2003). The issue of food safety has mainly provoked much attention because of public and consumer health concerns (Carvalho, 2006) and the rise of food borne illnesses and food emergencies (Sperling, 2010; Martin et al., 2003). In general, WHO (2010) concludes that all around the world "unsafe food causes many acute and life-long diseases, ranging from diarrheal diseases to various forms of cancer”. More specifically: “Approximately 76 million cases of food borne illness occur each year in the US, resulting in 323,000 hospitalizations and 5,200 deaths" (Sperling, 2010: 269). As a result of the concerns of food safety, developed countries go to less use of chemicals in agriculture and more "green products" in order to enhance food safety (Carvalho, 2006).

On the other hand, in many developing countries the question of food safety is far less an issue as food security still remains a great concern. Generally, in the 90s, the overall number of undernourished people stagnated. However, after the economic crisis in 2008, the number sharply rose (FAO, 2010). Luckily, the number of undernourished people in the world was estimated to have declined in 2010 as the global economy was expected to recover. Nevertheless, the number of undernourished people in developing countries remains unacceptably high: 925 million people are still suffering from undernourishment in 2010, of 
which, according to FAO (2010:10), two-third live in only seven developing countries (namely Bangladesh, China, the Democratic Republic of the Congo, Ethiopia, India, Indonesia and Pakistan). When looking at the figures, most people who are not able to afford enough food live in Asia and the Pacific: 578 million people are estimated to be undernourished in 2010, against 239 million in Sub-Saharan Africa. Yet, the proportion of undernourished people stays highest in Africa where $30 \%$ of the people are suffering from hunger (FAO, 2010). Moreover, even many more people in developing countries suffer from malnourishment as they face nutritional insecurity (Smith et al., 2000). These figures point to the intolerable high degree of undernourishment and malnourishment in developing countries.

Looking toward the future, it may be expected that undernourishment in the world will rise again as a consequence of two changes: population growth and climate change. The global population will continue to grow to a likely plateau at some 9 billion people by roughly the middle of this century (Charles et al., 2010). This challenges with food security as the global demand for food will increase for at least the coming 40 years (Charles et al., 2010). With respect to the climate change, it is probable that without sufficient adaptation measures, the climate will suffer from negative impacts on a few crops (such as wheat, rice, maize and rapeseed) that are important to large food-insecure human populations in South Asia and Southern Africa (Lobell et al., 2009). Furthermore, it is projected that the impacts of climate change on food security are significant with an estimated (wide) range of 5 million and 170 million additional people at risk of hunger by 2080 (Schmidhuber \& Tubiello, 2008: 19703).

As a consequence of the large differences in food security in developing and developed countries, the former moves into another direction than the latter. "They need to increase the agriculture production, and the use of crop protection chemicals seems a simple way for 
obtaining better crop yields" (Carvalho, 2006: 689). Moreover, improving food safety in developing countries may be too costly for them, as for example, new pesticides that are less harmful to the environment also tend to be more expensive (Carvalho, 2006).

\section{Organic agriculture: pro food safety or food security?}

\subsection{Organic agriculture and food security}

While food safety has become the main concern in developed countries, food security is a serious problem in developing countries. Accordingly, the debate over the ability of OA to feed the hungers in developing countries is heating up. According to the FAO, the potential of OA to produce high yields depends on previous farming systems used (Clean Production Action, 2005). Azadi and Ho (2010) believe that in developing countries, the implementation of OA diminishes the crops yield that depends on the intensity use of external inputs before shifting to organic. However, in the so-called Green Revolution areas (irrigated lands), such shift usually leads to almost identical yields and in traditional rain-fed agriculture, OA has the potential even to increase the yields. In fact, optimistic scholars (Badgley et al., 2007; Leu, 2004; Vasilikiotis, 2000) believe that OA has the potential to increase the yields, also in developing countries. With a global dataset of 293 samples, Badgley et al. (2007: 86) concluded that: "Organic agriculture has the potential to contribute quite substantially to the global food supply, while reducing the detrimental environmental impacts of conventional agriculture". They also concluded that OA is especially promising in developing countries as it can significantly increase the yields in those countries. Leu (2004) agrees with this view as he believes that OA can increase the yields where needed the most. He believes that OA has the potential to feed the world. Furthermore, OA is reported to have the largest potential increase in the yields of traditional agriculture (Setboonsarng, 2006). Also, the review study

by Vasilikiotis (2000) shows that OA has the possibility to reach higher yields than conventional farming in developing countries. 
Dierauer et al. (2006) are more careful in their predictions, but still somewhat optimistic towards OA. They estimate that yield reductions during the transition period from conventional to organic practices are 20 to 30 percent for cereals, 10 to 20 percent for maize, 30 to 40 percent for potatoes, 10 to 40 percent for vegetables and around 30 percent for fruits. However, in the medium and long terms, when soil fertility is recovered, the yields will only be slightly lower or even comparable to the pre-transition period.

However, pessimistic scholars (Gianessi, 2009; Connor, 2008) have argued that in short term, OA, compared to conventional and biotechnological approaches, cannot produce higher yields and the yields will decrease in most areas. One of these advocates is Connor (2008). He seriously criticizes Badgley et al. (2007) by stating that they "have seriously misinterpreted the ratios for developing countries, but more importantly have misunderstood the applicability of those ratios to their subsequent calculations of the productivity of organic agriculture" (Connor, 2008: 188). Connor (2008) then concludes that Bagley et al. (2007) have, to a large extent, overestimated the yield of OA. Gianessi (2009: 4) strongly agrees with Connor when he says "a close examination of the studies cited in these compilations [of examining the yields difference between organic and conventional agriculture] shows serious misinterpretations of the experiments leading to the unwarranted conclusion that organic agriculture can feed the world". Moreover, studies on different crops indicate a decline in yields when switching in OA. Examples include: lettuce (Polat et al., 2008), wheat (Annicchiarico et al., 2010; Kitchen et al., 2003), cauliflowers, onions (Dresbøll et al., 2008), cereal and potato (Mäder et al., 2002), and sweet corn (Dufault et al., 2008). Therefore, the debate on OA and its productivity is still far from getting proven.

\subsubsection{OA and access to food}


Although sufficient increase in the crops' yields of developing countries by organic practices may not, up till now, address food security, access to food is also crucial with respect to food security in these countries (Sen, 1981). Slight and Christman (2007) indicate that OA can contribute to food security in the sense that it can improve access to food. Also, UNEPUNCTAD (2008: 39) in its report on food security in Africa concludes the same. The report concludes: "a transition to integrated organic agriculture... has been shown to increase access to food in a variety of ways".

One example is given by Bruinsma (2003). According to her, because of its labor intensity, OA generates more employment opportunities in developing countries that stimulated local economy and the development of the region. Also, many researchers (Kilcher, 2007; Willer \& Yussefi, 2007; Parrot \& Van Elzakker, 2003; Kotschi et al., 2003; Parrott \& Marsden, 2002) believe that the characteristics of OA make this approach capable to contribute to economic aspect of sustainable development in developing countries. Ramesh et al. (2005) even consider OA as a development tool for India. Furthermore, they conclude: "By adopting organic agriculture, farmers are challenged to take on new knowledge and perspectives, and to innovate. This leads to an increased engagement in farming which can trigger greater opportunities for rural employment and economic upliftment" (Ramesh et al., 2005: 566). Such findings are important with respect to access to food since poverty and purchasing power are mentioned as the greatest causes of undernourishment, because food availability in many cases is not a problem per se (Jaron \& Galal, 2009; Smith et al., 2000) but also it tightly relates to the individuals' purchasing power. In other words, when an individual does not have a job, s/he cannot go to market because simply there is no money to afford something. However, the findings presented here are not based on empirical findings. Therefore, a series of risk assessment studies on the potential of OA to contribute to food access is necessary. 
Furthermore, recent studies in China and Brazil found that conversion to OA has improved market access (Oelofse et al., 2010). Improved market access is important in overcoming inequalities in access to food. However, many organic farmers in developing countries have difficulty in accessing organic markets (Giovannucci, 2006; Pretty et al., 2003). "Access to markets is essential for all farmers, as surplus crops can be sold to generate income" (Slight \& Christman, 2007: 8). Markets for organic products are still underdeveloped in developing countries, especially compared to markets for conventional agricultural products. If well developed markets for organic products are there, they will mainly be international-oriented than local (Rehber \& Tulhan, 2002). Accordingly, for food security in developing countries it is important that local and domestic markets are also developed.

\subsection{Organic agriculture and food safety}

The benefits of OA for food safety have been stated by many authors (Azadi \& Ho, 2010; Lairon, 2010; Rembiałkowska, 2007; Carvalho, 2006; Winter \& Davis, 2006; Lu et al., 2006). First, organic crops tend to contain fewer nitrates and nitrites (Rembiałkowska, 2007). "This is important, because nitrates can easily be converted into nitrites, which can cause a dangerous illness called methaemoglobinaemia in babies, infants and elderly people" (Rembiałkowska, 2007: 2758). Also, Rembiałkowska (2007: 2759) states “All available results show that the content of pesticide residues is significantly lower in organic crops, which creates safer health conditions for consumers eating organically". Winter and Davis (2006) state that the frequency of measurable residues in organic products is three to four times lower than conventional products. Furthermore, the French Agency for Food Safety performed an up-to-date exhaustive and critical evaluation of the nutritional and sanitary quality of organic food and concluded that: a) the vast majority (94-100\%) of organic food 
does not contain any pesticide residues and, b) organic vegetables contain markedly less nitrates (about 50\%) (Lairon, 2010). The amount of pesticide residues is important with respect to food safety and health issues, as pesticide exposure is associated with various health risks, such as Parkinson's Disease (Hancock et al., 2008; Ascherio et al., 2006), subtle effects on the immune system (Steerenberg et al., 2008; Nagayama et al., 2007) and potential negative effects on reproductive health (Mendola \& Buck Louis, 2010; Andersen et al., 2008). Also, the consumption of organic products is linked to a lower risk of eczema in children (Benbrook \& Greene, 2008). It should however be mentioned that "there are no published reports of health risks for consumers related to the types of pesticides allowed in (some forms of) OA, such as copper chloride or plant extracts" (FAO, 2007: 6).

Regarding food quality, many consumers believe that organically grown crops are more nutrient and have a better quality (Ekelund \& Tjärnemo, 2004). Rembiałkowska (2007) confirms that "many studies have proved quite unequivocally that vegetables and fruits from organic farms have a better taste and smell. This was found for carrots and potatoes, celery and red beetroot, head cabbage and tomatoes as well as for apples, cherries and redcurrants" (Rembiałkowska, 2007: 2760). In addition, he states “organic crops contain... as a rule, more dry matter, vitamin $\mathrm{C}$, phenolic compounds, essential amino acids and total sugars than conventional crops. Organic crops also contain statistically more mineral compounds and usually have better sensory and long-term storage qualities" (Rembiałkowska, 2007: 2757). Benbrook and Greene (2008) point to the higher levels of good fats and antioxidants in organic food products. Others (Chassy et al., 2006; Asami et al., 2003; Heaton 2001; Weibel et al., 2000) have also found a higher antioxidant content in organic crops. In a long-term study, Mitchel et al. (2007) found that health-promoting flavonoids in organic products are twice more than in conventional tomatoes. Furthermore, higher mineral and general vitamin content (Worthington, 1998), better flavor (Reganold et al., 2001; Weibel et al., 2000), more 
iron, magnesium and phosphorus (Worthington, 2001) are found in organic crops compared to conventional crops.

However, the results regarding nutritional advantages of organic products still remain as a debate. Williamson (2007) indicates that many conducted researches in this field are low quality and "much more good-quality research is needed to confirm these findings". He states "Overall there is a trend for higher nutrient levels in organic produce, including vitamin $\mathrm{C}$ and some other micronutrients (range 9-42\%), although this does not apply to all nutrients or all crops" (Williamson, 2007: 104). Other studies have resulted in conclusions that differences in quality and nutritive value of organically and conventionally grown foods are inconsistent or non significant (Bourn \& Prescott 2002; Worthington 1998; Woese et al., 1997). "The most consistent data are those available for vitamin $C$ and nitrate, which support beneficial effects of organic production on levels of these nutrients" (Williams, 2002: 21). This could mean that OA could enhance nutritional safety. However, according to several scholars (Barrett et al., 2007; Williamson, 2007; Williams, 2002) it may be too early to conclude that, from a nutritional perspective, organic products are superior to the conventional ones.

\section{Trade-off between sustainability and productivity}

Thus far discussed (see an overview of main potentials of OA in Table 1), OA can have doubtful potential to secure enough food while there is no doubt on its potential to provide consumers with safer food and more sustainable food production. Also, access to food can, to a certain extend, be enhanced, although this is limited as market access is not improved in developing countries and the contributions of OA to development and poverty reduction (which would enhance the individuals' purchasing power) are mainly indirect. With respect to food availability, conventional and biotechnological approaches still appear to produce 
higher yields around the world. Hence, we still need the other approaches for their higher productivity. The reason simply is that we cannot ignore the 925 million hungers in developing countries (FAO, 2010). At the moment, food policies in developing countries cannot propose lower crop yields as this would worsen the problem of undernourishment.

[insert Table 1 around here]

However, OA could, in the long term, also be considered as an important contributor to food security, as it addresses several issues as follow:

1. the population growth, especially in developing countries asks for more efficient use of resources and less dependent on non-renewable resources;

2. the problem of land degradation is threatening food security and is expected to be worsened;

3. taking into account climate change which calls for adaptation of agricultural systems to more extreme weather events in order to keep crops yields sustainable; and

4. pest management problems which threaten food security and which are expected to be worsened as a result of climate change.

Thereby, a shift to OA will be more and more necessary in order to renewing the resources (mainly water and soil) to secure food security in the future. In other words, compared to the other approaches, OA:

1. uses water more efficiently (Thierfelder Muller \& Davis, 2009; Thierfelder \& Wall, 2009; Giller et al., 2003; Lotter et al., 2003);

2. relies much less on fossil fuels (Scialabba \& Müller-Lindenlauf, 2010);

3. prevents land degradation and even improves soil fertility (Niggli et al., 2007; Kaihura et al., 1999);

4. is more resistant to drought(Muller \& Davis, 2009; Thierfelder \& Wall, 2009; Lotter et al., 2003; Ramesh et al., 2005); 
5. produces higher yields under dry conditions (Muller \& Davis, 2009; Thierfelder \& Wall, 2009; Lotter et al., 2003; Ramesh et al., 2005);

6. includes local knowledge/varieties (Willer \& Yussefi, 2007; Muller \& Davis, 2009); and

7. is more resistant to pests (Meyling et al., 2010; Birkhofer et al., 2008; Letrouneau \& Bothwell, 2008; Badgley et al., 2007; FAO, 2007; Marinari et al., 2006).

On top of these advantages, OA contributes to climate change mitigation (Scialabba \& Müller-Lindenlauf, 2010; Niggli et al., 2007; Borron, 2006; Kotschi \& Müller-Sämann, 2004; Hansen et al., 2001; Hodge, 1993) and stimulates biodiversity (Norton et al., 2009; Mäder et al., 2002).

The total mitigation benefits of $\mathrm{OA}$ are hard to measure, as it is highly dependent on local environmental conditions and management practices. However, "Should all agricultural systems be managed organically, the omission of mineral fertilizer production and application is estimated to reduce the agricultural GHG emissions by about $20 \%-10 \%$ caused by reduced $\mathrm{N} 2 \mathrm{O}$ emissions and about $10 \%$ by lower energy demand. These avoided emissions are supplemented by an emission compensation potential through carbon sequestration in croplands and grasslands of about $40-72 \%$ of the current annual agricultural GHG emissions" (Scialabba \& Müller-Lindenlauf, 2010: 165).

Regarding biodiversity, organic farming appears to be associated with increased species richness and abundance for plants, predatory invertebrates and birds" (Fuller et al., 2005: 431). There has been pointed at the beneficial influence of OA on: invertebrate feeders [farmland birds] (Smith et al., 2010), insect pollinated plants (Gabriel \& Tscharntke, 2007), bee diversity and flower cover (Holzschuh et al., 2007) and plant species richness (Rundlöf et al., 2010). 
Nevertheless, according to Hülsebusch et al. (2007), OA can be able to meet food security. They believe, in long-run, the output of OA per unit of area would be higher, because there is no loss of cultivation area and natural resources are saved. The negative effects of conventional agriculture on biodiversity (Spangenberg, 2007; Hole et al., 2005), the aquatic environment (Pimentel et al., 2005; Tilman, 1998; Carvalho et al., 1997; Baskin, 1994), pest outbreaks (Zhu et al., 2000; Conway \& Pretty, 1991) and soil fertility (Woods, 2009; Bullock, 1997; Hollinger et al., 1998) will, in the end, cause pressure on food security. This is because less fertile soil, susceptibility to disease and low biodiversity result in lower yields per hectare. Furthermore, conventional agriculture is less resistant to drought (Ramesh et al., 2005) and uses water less efficiently (Lotter et al., 2003). Such benefits are very important with respect to climate change. Moreover, the failure of the two other approaches (conventional and biotechnological) to include indigenous knowledge (Niggli et al., 2008) is a serious lack as such knowledge contributes positively to climate resilience (Niggli et al, 2008; Muller \& Davis, 2009) and access to food (Slight \& Christman, 2007). Therefore, in general, OA could, in long run, be more conducive to meet food security.

However, as OA, at least in short-term, produces lower crop yields, there are some kind of tradeoffs between organic and the two other approaches with respect to sustainability (in terms of long term potentials to produce enough food) and productivity. This means that although $\mathrm{OA}$ in the short term may produce fewer, in the long term may produce higher yields because it can better address important threats to food security such as soil degradation, climate change and pest problems. However, as said, we cannot ignore the 925 million hungry people in the world today. Hence, given the current situation regarding the productivity of OA, we still need conventional and biotechnological approaches to feed the hunger mounts. 


\section{Discussion}

Although OA could, in the long term, be more capable to meet food security, there are still some challenges that OA has to face (see an overview of main challenges of OA in Table 2). Overall, political efforts are important to appreciate more and more the benefits of OA (Stockdale et al., 2001: 263), since in many developing countries, well developed policies with respect to OA are not yet made (Taylor, 2006). If supportive policies regarding OA are in place, they mainly focus on seeking to earn, through exports, foreign exchange for other development needs (Scialabba, 2000). However, it is important to note that domestic markets for organic products are not developed as well; the important element that does not exist at the moment. Rundgren (2006: 3), in his report "Best practices for organic policy: what developing countries' governments can do to promote the organic sector" provides the following recommendations to developing countries:

- "To link any organic policy and action plans to the overarching objectives of the country's agriculture policies;

- To give recognition and encouragement to the organic sector;

- To remove obstacles to and biases against organic agriculture;

- To train relevant staff in organic farming;

- That there is an integrated approach that takes all aspects of organic farming into consideration as well as the different stakeholders;

- That governments mainly take an enabling and facilitating role rather than a controlling one;

- That the sector itself is organized and that there is close collaboration between the sector and government”. 
We consider these policy recommendations essential for some specific challenges that OA has to face. These challenges need to be addressed appropriately for OA in order to effectively fight undernourishment in developing countries in long term. First, research should be stimulated on how to further improve the "productivity of organic farming", especially in developing countries. Already some researchers indicate possible methods to improve the yields. One of the methods concerns the way of selecting crop varieties for organic farming. According to Murhpy et al. (2007: 172) “increasing yield in organic systems through breeding will require direct selection within organic systems rather than indirect selection in conventional systems" (Murphy et al., 2007: 172). This is confirmed by recent genetic studies on maize and wheat, which have shown that selecting under organic and lowexternal-input agriculture can improve yields and yield stability considerably (Burger, et al., 2008; Löschenberger et al., 2008). However, research in developing countries with the use of local varieties is still very limited. Moreover, in most of developing countries, few research agencies have emerged for the organic sector (Giovannucci, 2005; 2006).

Second, as the access to organic markets for many farmers in developing countries is still very limited (Giovannucci, 2006; Pretty et al., 2003), policies should stimulate the "development of domestic organic markets" in developing countries. Famers need to be able to sell their surplus easily. However, "as markets support organic expansion, there is often a ripple effect, spurring development of related enterprises such as those that supply compost, bio-pest and disease control stocks, seeds, plants, and other inputs, as well as crop-handling and processing facilities" (Slight \& Christman, 2007: 9). Furthermore, when considering the access to markets, the point of certification is important to be considered. Still, certification may be mainly important in later stages of market development, as certification is specifically relevant with respect to access to the international organic market (Rehber \& Tulhan, 2002). "For domestic markets, having a common and clear organic standard (voluntary or otherwise) 
is more important than regulations, particularly at the early stages. It should be developed consensually with all of the key stakeholders and be reasonably simple for producers to apply and certifiers to verify" (Giovannucci, 2006: 18). In addition, Vaarst et al. (2009:20) suggest that "the organic sector should focus on the whole certification system and ensure that it can be owned by the farmers. This will strengthen the ownership and the courage for real development".

The third issue that needs to be addressed by government policies is "managerial knowledge" about organic practices of farmers in developing countries. Some researches indicate that small-scale farmers who practice unimproved traditional farming are not likely to be interested in alternative techniques (Crucefix, 1998). However, the motivation of the farmer is closely linked to their knowledge about organic farming, since many farmers in developing countries have doubts about the potential of OA to increase their yields. It appears that if farmers in developing countries are more aware about the benefits and opportunities of OA to improve food security, their willingness to apply OA will probably increase (Crucefix, 1998). Such knowledge is also very important because the farmers' practical actions rely heavily on such knowledge. Training, extension and demonstration are possibly even more critical in organic than in conventional agriculture (Crucefix, 1998; Demiryürek et al., 2008) as organic approach is mostly a managerial method. In addition, OA is based on ecological processes. The agro-ecosystem knowledge is therefore a precondition to any organic farm (Borron, 2006). This also relates to potential to increase organic productivity in developing countries as scientists pointed that knowledge seems one of the key factors to improve agriculture efficiency and increase the yields in developing countries (Bravo-Ureta \& Pinheiro, 1993).

Finally, there are two aspects which are important in contributing to overcoming the above-mentioned challenges: institutional development and the development of farmers' 
organizations. Regarding the institutional development, Giovannucci (2006: 20) states "Perhaps the single most important factor for successful organic adoption is the availability of reliable institutional support systems (local and national) that can initially help make available the many necessary components of a successful transition...”. Input subsidies and price supports are also important (Giovannucci, 2006; Demiryürek et al., 2008) as well as increasing organic farmers' access to local credits (FAO, 2007: 13). This is especially vital during the transition period: farmers may face decreasing yields and hence a decline in income. However, the costs of certification also put a burden on the farmer. Moreover, institutions could support and stimulate research facilities that are necessary to enhance knowledge on how to improve the productivity of OA.

Besides, the development of farmers' organizations is important to strengthen farmer's knowledge and collective bargaining power in order to "effectively negotiate with a larger private sector partner (buyer, contract farm, out grower manager)" (Giovannucci, 2006:

21). Likewise, Slight \& Christman (2007: 11) point to the importance of farmers' organizations for market access: "the most effective strategy for creating and optimizing market access is for small farmers to organize into cooperatives or other democratically run grower groups". Hence, developing supportive institutions and farmers' organizations is vital to overcome the obstacles of the transition to OA in developing countries.

[insert Table 2 around here]

\section{Conclusion}

Land degradation, the scarcity of resources, acute and chronic droughts, erratic rainfall, and pest problems are the most important threats to food security that will put further pressure on food security in the future because of the increasing changes in the global climate. This is particularly true in developing countries where the population growth remains highest and people are most vulnerable to negative impacts of the changes. OA has the potential to 
address such important threats in different ways. It stands as a good alternative for conventional agriculture which has had a devastating influence on land degradation, pest management, and biodiversity as the most serious hazards for the productivity of conventional agriculture. Conversely, the concerns about food safety in conventional and biotechnological approaches in agriculture are growing. Furthermore, these two approaches might be less able to cope with extreme weather catastrophes that give an important role to OA as a more flexible alternative to deal with climate change, biodiversity, and sustainable food production. All these make OA, in long run, a major approach to fight undernourishment also in developing countries.

However, there still remain some major challenges to overcome when switching in OA: the productivity of OA, its managerial knowledge, institutional supports, the development of farmers' organizations, and market access to organic products. Hence, we still need both conventional and biotechnological approaches to feed the hungers in developing countries. Accordingly, we emphasize on providing farmers in developing countries with the possibility of implementing different approaches. Obviously, farmers in developing countries cannot accept lower yields and therefore a decreased income when implementing a new approach like OA, may increase the risk of undernourishment. Given the present enormous food crisis, there is an urgent obligation to protect people in developing countries from such risks. Hence, a transitional period that should be gradual and sufficiently address the challenges when switching in OA is very crucial to launch a productive OA and deal successfully with undernourishment in developing countries. Therefore, policy makers should be aware of a realistic and gradual transition from the other approaches to the organic that should be projected only in "long run", and after assessing ex ante values (i.e. expected bio-physical and socio-economic gains and losses that may result from the transition) in the 
framework of conducting a series of risk assessment studies on the bases of both "crop-case" and "region-case".

\section{References}

Andersen, H.R., Schmidt, I.M., Grandjean, P., et al. (2008). Impaired Reproductive Development in Sons of Women Occupationally Exposed to Pesticides during Pregnancy. Environmental Health Perspectives 116: 566-572.

Annicchiarico, P., Chiapparino, E., and Perenzin, M. (2010). Response of common wheat varieties to organic and conventional production systems across Italian locations, and implications for selection. Field Crops Research 116: 230-238.

Asami, D.K., Hong, Y.H., Barrett, D.M., and Mitchell, A.E. (2003). A comparison of the total phenolic and ascorbic acid contents of freeze-dried and air-dried marionberry, strawberry and corn grown using conventional, organic and sustainable agricultural practices. Journal of Agricultural and Food Chemistry 51: 1237-1241.

Ascherio, A. Chen, H., Weisskopf, M.G., et al. (2006). Pesticide Exposure and Risk for Parkinson's Disease. Annual Neurology 60: 197-203.

Azadi, H., and P. Ho (2010). Genetically modified and organic crops in : A review of options for food security. Biotechnology Advances 28: 160-168.

Badgley, C., Moghtader, J., Quitero, E., Zakem, E., et al. (2007). Organic agriculture and the global food supply, Renewable Agriculture and Food Systems 22: 86-108.

Barrett, D.M., Weakley, C., Diaz, J.V., and Watnik, M. (2007). Qualitative and nutritional differences in processing tomatoes grown under commercial organic and conventional production systems. Journal of Food Science 72: 441-451.

Baskin, Y. (1994). Ecosystem function of biodiversity. BioScience 44: 657-660. 
Benbrook, C., and Greene, A. (2008). The link between organic and health: New research makes the case for organic even stronger. Organic Processing Magazine, retrieved $11^{\text {th }} \quad$ of $\quad$ December 2010 from $<\mathrm{http}: / / \mathrm{www}$.organiccenter.org/reportfiles/OPma08CoverStory2.pdf>

Bhatta, G.D., Doppler, W., and Bahadur K. (2009). Potentials of Organic Agriculture in Nepal. Journal of Agriculture and Environment 10: 1-11.

Birkhofer, K., Bezemer, M.T., Bloem, J., Bonkowsk, M., et al. (2008). Long-term organic farming fosters below and aboveground biota: Implications for soil quality, biological control and productivity. Soil Biology and Biochemistry 40: 2297-2308.

Borron, S. (2006). Building Resilience for an Unpredictable Future: How Organic Agriculture Can Help Farmers Adapt to Climate Change. FAO: Rome.

Bouagnimbeck, H. (2009). Organic Farming in Africa. In Willer, H. \& L. Klicher (Eds.) (2009). The World of Organic Agriculture. Statistics and Emerging Trends 2009. IFOAM, Bonn, FiBL, Frick, ITC, Geneva.

Bourn, D., and Prescott, J. (2002). A comparison of the nutritional value, sensory qualities and food safety of organically and conventionally produced foods. Critical Reviews in Food Science and Nutrition 42: 1-34.

Bravo-Ureta, B.E. and Pinheiro, A.E. (1993). Efficiency analysis of developing country agriculture: A review of the frontier function literature. Agricultural and Resource Economics 2: 88-101.

Bruinsma, J. (2003). World Agriculture: Towards 2015/2030. FAO: Rome.

Bullock, K.P. (1997). Sustainable development of soils in Western Europe. An overview. In Ponencias Edafologı'a: Conferences in the 50th Commemorative Meeting of the Spanish Soil Science Society, Madrid, Spain (pp. 109-123). Madrid: Consejo Superior de Investigaciones Científicas. 
Burger, H., Schloen, M., Schmidt, W., and Geiger, H.H. (2008) Quantitative genetic studies on breeding maize for adaptation to organic farming. Euphytica 163: 501-510.

Carvalho, F.P. (2006). Agriculture, pesticides, food security and food safety. Environmental Science and Policy 9: 685-692.

Carvalho, F.P., Fowler, S.W., Villeneuve, J.-P., and Horvat, M. (1997). Pesticide residues in the marine environment and analytical quality assurance of the results. In: Proceedings of an International FAO/IAEA Symposium on the Environmental Behavior of Crop Protection Chemicals (pp. 35-57). IAEA: Vienna.

Charles, J., Godfray, J., Beddington, J.R., et al. (2010). Food security: The challenge of feeding 9 billion people. Science 327: 812-818.

Chassy, A., Bui, L., Renaud, E.N.C., Van Horn, M., and Mitchell, A. (2006). Three-year comparison of the content of antioxidant microconstituents and several quality characteristics in organic and conventionally managed tomatoes and bell peppers, Journal of Agricultural and Food Chemistry 54: 8244-8252.

Clean Production Action (2005). Organic and sustainable farming. Available on: http://www.cleanproduction.org/BioSociety/sustainablefarming.htm Retrieved Aug. $10,2009$.

Connor, D.J. (2008). Organic Agriculture cannot feed the world. Field Crops Research 106: 187-190.

Conway, G.R., and Pretty, J. (1991). Unwelcome Harvest: Agriculture and Pollution. Earthscan, London.

Crucefix, D. (1998). Organic Agriculture and Sustainable Rural Livelihoods in Developing Countries. $\quad$ Retrieved $12^{\text {th }}$ of $\quad$ October 2009 from <http://www.grupochorlavi.org/organicos/doc4.pdf> 
Demiryürek, K., Stopes, C., and Güzel, A. (2008). Organic agriculture: the case of Turkey. Outlook on Agriculture 37: 261-267.

Dierauer, H., Weidmann, G., and Heller, S. (2006). Umstellung auf Bio. Erfolgreich in den Biolandbau starten. Merkblatt. FiBL: Frick, Switzerland.

Dresbøll, D.B., Bjorn, G.K., and Thorup-Kristensen, K. (2008). Yields and the extent and causes of damage in cauliflower, bulb onion, and carrot grown under organic or conventional regimes. Journal of Horticultural Science and Biotechnology 83: 770776.

Dufault, R.J., Hester, A., and Ward, B. (2008). Influence of organic and synthetic fertility on nitrate runoff and leaching, soil fertility, and sweet corn yield and quality. Communications in Soil Science and Plant Analysis 39: 1858-1874.

Ekelund, L., and Tjärnemo, H. (2004). Consumer preferences for organic vegetables - the case of Sweden. Acta Horticultarae 655: 121-128.

Eswaran, H., Lal, R., and Reich, P.F. (2001). Land degradation: an overview. In: Bridges, E.M., Hannam, I.D., Oldeman, L.R., Pening de Vries, F.W.T., Scherr, S.J., \& S. Sompatpanit (eds.). Responses to Land Degradation. Proc. 2nd. International Conference on Land Degradation and Desertification, Khon Kaen, Thailand. Oxford Press: New Delhi, India.

Falkenmark, M., Lundqvist, J., Klohn, W., et al.(1998). Water scarcity as a key factor behind global food insecurity: Round table discussion. Ambio 27: 148-154.

FAO (2010). The state of food insecurity in the world. FAO: Rome.

FAO (2007). Organic Agriculture and Food Utilization. FAO: Rome.

FAO (2003). Trade Reforms and Food Security - conceptualizing the linkages. FAO: Rome. $\begin{array}{lllll}\text { Retrieved } & 7^{\text {th }} & \text { of } & \text { January } & 2011\end{array}$ <ftp://ftp.fao.org/docrep/fao/005/y4671e/y4671e00.pdf> 
FAO/WHO (1997). Risk Management and Food Safety-Report of an FAO/WHO Expert Consultation, FAO Food and Nutrition Paper No. 65, (Joint FAO/WHO Expert Consultation on risk management and food safety. 27-31 January, Rome, Italy). Rome: FAO.

Fuller, R.J., Norton, L.R., Feber, R.E., et al. (2005). Benefits of organic farming to biodiversity vary among taxa. Biology Letters 1: 431-434.

Gabriel, D., and Tscharntke, T. (2007). Insect pollinated plants benefit from organic farming. Agriculture, Ecosystems and Environment 118: 43-48.

Gianessi, L. (2009). The potential for organic agriculture to feed the world is being oversold. Outlooks on Pest Management 20: 4-5.

Giller K.E., Bignell, D., Lavelle, P., Swift, M., et al. (2003). Soil Biodiversity in Rapidly Changing Tropical Landscapes: Scaling down and Scaling up. In: Bardgett RD, MB Usher, and DW. Hopkins (eds) Biological Diversity and Function in Soils. Cambridge University Press: New York.

Giovannucci, D. (2005). Organic Agriculture and Poverty Reduction in Asia: China and India focus, IFAD Office of Evaluation: Rome

Giovannucci, D. (2006). Salient Trends in Organic Standards: The Opportunities and Challenges for Developing Countries. In: Standards and Trade: Challenges and Opportunities for Developing Country Agro-Food Trade Course. Washington, DC: World Bank Institute-USAID, Trade Standards Working Group.

Gross, R., Schoeneberger, H., Pfeifer, H., and Preuss, H.J. (2000). Four Dimensions of Food and Nutrition Security: Definition and Concepts. In: ACC/SCN News, UN ACC SubCommittee on Nutrition, No 20, July: pp 20-25. 
Hansen, B., Alrøe, H., and Kristensen, E.S. (2001). Approaches to assess the environmental impact of organic farming with particular regard to Denmark. Agriculture, Ecosystems and Environment 83: 11-26.

Heaton, S. (2001). Organic Farming, Food Quality and Human Health: A Review of the Evidence. Soil Association: Bristol, U.K.

Hodge, I. (1993). Sustainability: putting principles into practice. An application to agricultural systems, Paper presented to 'Rural Economy and Society Study Group', Royal Holloway College, December 1993.

Hole, D.G., Perkins, A.J., Wilson, J.D., Alexander, I.H., Grice, P.V., and Evans, A.D. (2005). Does organic farming benefit biodiversity? Biological Conservation 122: 113-130.

Hollinger, E., Baginska, B., and Cornish, P.S. (1998). Factors influencing soils and nutrients loss in storm water from a market garden. In Proceedings of the $9^{\text {th }}$ Australian Agronomy Conference (Ed. Australian Society) (pp. 741-744). Wagga Wagga, Australia: Australian Society of Agronomy.

Holzschuh, A., Steffan-Dewenter, I., Kleijn, D. and Tscharntke, T. (2007). Diversity of flower-visiting bees in cereal fields: effects of farming system, landscape composition and regional context. Journal of Applied Ecology 44: 41-49.

Hülsebusch, C., Wichern, F., Hemann, H., \& P. Wolff (eds.) 2007: Organic Agriculture in the Tropics and the Subtropics - Current Status and Perspectives Supplement No. 89 to the Journal of Agriculture and Rural Development in the Tropics and Subtropics, Kessel University Press, GmbH.

Jaron, D., and Galal, O. (2009). Food security and population health and well being, Asia Pacific Journal of Clinical Nutrition 18: 684-687.

Jenkins J.C., and Scanlan, S.J. (2001). Food Security in Less Developed Countries, 1970 to 1990. American Sociological Review 66: 718-744. 
Gross, R., Schoeneberger, H., Pfeifer, H., and Preuss, H.A. (2000). The Four Dimensions of Food and Nutrition Security: Definitions and Concepts. In: ACC/SCN News, UN ACC Sub-Committee on Nutrition, No 20, July: pp 20-25.

Hancock, D.B., Martin, E.R., Mayhew, G.M. et al. (2008). Pesticide exposure and risk of Parkinson's disease: A family-based case-control study. BMC Neurology 8: 6. $\begin{array}{llll}\text { Retrieved } & \text { November } & 30 \text { th } & 2010\end{array}$ http://www.biomedcentral.com/content/pdf/1471-2377-8-6.pdf

Kaihura, F.B.S., Kullaya, I.K., Kilasara, M., Auned, J.B., Singh, B.R., and Lal, R. (1999). Soil quality effects of accelerated erosion and management systems in three ecoregions of Tanzania. Soil \& Tillage Research 53: 59-70.

Kilcher, L. (2007). How organic agriculture contributes to sustainable development. Journal of Agricultural Research in the Tropics and Subtropics 89: 31-49.

Kitchen, J.L., McDonald, G.K., Shepherd, K.W., Lorimer, M.F., and Graham, R.D. (2003). Comparing wheat grown in South Australian organic and conventional farming systems. 1. Growth and grain yield. Australian Journal of Agricultural Research 54: 889-901.

Kotschi, J., Bayer, W., Becker, T., and Schrimpf, B. (Eds.) (2003). Alter Organic: Local Agendas for Organic Agriculture in Rural Development. Agrecol e.V., Marburg, Bonn-Königswinter.

Kotschi, J., and Müller-Sämann, K. (2004). The Role of Organic Agriculture in Climate Change Mitigation. IFOAM: Bonn.

Kung Wai, O. (2007). Organic Farming in Asia. In Willer, H., \& Yussefi, M.(eds.) (2007). The World of Organic Agriculture. Statistics and Emerging Trends 2007. 9th edition, totally revised and updated. International Federation of Organic Agriculture 
Movements IFOAM, Bonn, Germany \& Research Institute of Organic Agriculture FiBL, Frick, Switzerland.

Lairon, D. (2010). Nutritional quality and safety of organic food. A review. Agronomy for Sustainable Development 30: 33-41.

Lee, H.C., Walker, R., Haneklaus, S., Philips, L., Rahmann, G., and Schnug, H. (2008). Organic farming in Europe: A potential major contribution to food security in a scenario of climate change and fossil fuel depletion. Landbauforschung Volkenrode 58: $145-151$.

Leu, A. (2004). Organic Agriculture Can Feed the World. ACRES USA 34: 1-4.

Lobell, D.B., Burkel, M.B., Tebaldi, C., Mastrandrea, M.D., Falcon, W.P., and Naylor, R.L. (2009). Prioritizing climate change adaptation needs for food security in 2030. Science 319: 607-610.

Löschenberger, F., Fleck, A., Grausgruber, H., Hetzendorfe, H., et al. (2008) Breeding for organic agriculture: the example for winter wheat in Austria. Euphytica 163: 469-480.

Lotter, D.W., Seidel, R., and Liebhardt, W. (2003). The performance of organic and conventional cropping systems in an extreme climate year. American Journal of Alternative Agriculture 18: 146-154.

Løvendal, C.R., and Knowles, M. (2005). Tomorrow’s Hunger: A framework for analyzing vulnerability to food insecurity. ESA working paper No. 05-07. FAO: Rome.

Lu, C., Toepel, K., Irish, R., Fenske, R.A., Barr, D.B., and Bravo, R. (2006). Organic diets significantly lower children's dietary exposure to organophosphorus pesticides. Environmental Health Perspectives 114: 260-263.

Mactaggart, M. (2010). Working with Nature. In Food Security (ISSN 2044-3269). Platinum Media Consulting: London. Retrieved $7^{\text {th }}$ of January 2011 from <http://www.feedingthefuture.eu/FS/foodsecurity.pdf> 
Mäder, P., Fließbach, A., Dubois, D., Gunst, L., Fried, P., and Niggli, U. (2002). Soil fertility and biodiversity in organic farming. Science 296: 1694-1698.

Maitani, T. (2005). Establishment of standards and specifications for chemical substances in foods and evaluation of exposure to maintain food safety. Bulletin of National Institute for Health Sciences 123: 1-11.

Marinari, S., Mancinelli, R., Campiglia, E., and Grego, S. (2006). Chemical and biological indicators of soil quality in organic and conventional farming systems in Central Italy, Ecological Indicators 6: 701-711.

Martin, T., Dean, E., Hardy, B., Johnson, T., Jolly, F., Matthews, F., et al. (2003). A new era for food safety regulation in Australia. Food Control 14: 429-438.

Mechlem, K. (2004). Food Security and the right to food in the discourse of the United Nations. European Law Journal 10: 631-648.

Mendola, P., and Buck Louis, G.M. (2010). Environmental Contaminants, female reproductive health and fertility. In Woodruff, T.J., Janssen, S.J., Guillette, L.J. \& L.C. Giudice (eds.), Impacts of Reproductive Health and Fertility (pp. 161-172), Cambridge University Press: Cambridge.

Meyling, N.V., Navntoft, S., and Eilenberg, J. (2010). Organic farming systems benefit biodiversity and natural pest regulation in white cabbage, retrieved $12^{\text {th }}$ of December 2010 from <http://orgprints.org/16988/1/16988.pdf>

Middleton, N. (2008). Environment today: food security. Geography Review 22: 24-26.

Muller, A., and Davis, J.S. (2009). Reducing Global Warming: The potential of Organic Agriculture, $\quad$ retrieved $\quad$ December $\quad 11^{\text {th }} \quad 2010 \quad$ from $<$ http://orgprints.org/16507/1/mueller-and-davis-2009-

ReducingGlobalWarming_PolicyBrief.pdf> 
Murphy, K.M., Campbell, K.G., Lyon, S.R., and Jones, S.S. (2007). Evidence of varietal adaption to organic farming systems. Field Crops Research 102: 172-177.

Nagayama, J., Tsuji, H., Iida, T., et al. (2007). Immunologic effects of perinatal exposure to dioxins, PCBs and organochlorine pesticides in Japanese infants. Chemosphere 67: 393-398.

Niggli, U., Early, J., and Ogorzalek, K. (2007). Issues Paper: Organic Agriculture and environmental stability of the food supply, retrieved $20^{\text {th }}$ of December 2010 from http://orgprints.org/10752/1/niggli-et-al-2007-environmental-stability.pdf

Niggli, U., Schmid, H., and Fließbach, A. (2008). Organic Farming and Climate Change. International Trade Centre (ITC): Geneva.

Norton, L., Johnson, P., Joys, A., Stuart, R., et al. (2008 or 9). Consequences of organic and non-organic farming practices for field, farm and landscape complexity. Agriculture, Ecosystems and Environment 129: 221-227.

OECD (2008). OECD Health Data 2010 - Selected Data: Risk factors, retrieved $17^{\text {th }}$ of November 2010 from <http://stats.oecd.org/index.aspx>

Oelofse, M., Høgh-Jensen, H., Abreu, L.S. et al., (2010). Certified organic agriculture in China and Brazil: Market accessibility and outcomes following adoption. Ecological Economics 69: 1785-1793.

Parrott, N., and Marsden, T. (2002). The real green revolution. Organic and agroecological farming in the South. Greenpeace Environmental Trust: London.

Pimentel, D., Hepperly, P., Hanson, J., Douds, D., and Seidel, R. (2005). Environmental, energetic, and economic comparisons of organic and conventional farming systems. Bioscience 55: 573-582.

Pingali, P., Alinovi, L., and Sutton, J. (2005). Food security in complex emergencies: enhancing food system resilience. Disasters 29: 5-24. 
Pinstrup-Andersen, P. (2009). Food security: definition and measurement. Food Security 1: $5-7$.

Polat, E., Demir, H., and Onus, A.N. (2008). Comparison of some yield and quality criteria in organically and conventionally-grown lettuce. African Journal of Biotechnology 7: 1235-1239.

Pretty, J.N., Morison, J.I.L., and Hine, R.E. (2003). Reducing food poverty by increasing agricultural sustainability in developing countries. Agriculture, Ecosystems and Environment 95: 217-234.

Pretty, J.N., Noble, A.D., Bossio, D., Dixon, J., Hine, R.E., Penning De Vries, F.W.T., and Morison, J.I.L. (2006). Resource-conserving agriculture increases yields in developing countries. Environmental Science and Technology 40: 1114-1119.

Ramesh, P., Singh, M., and Rao, A.S. (2005). Organic farming: its relevance to the Indian context. Current Science 88: 561-568.

Reganold, J.P., Glover, J.D., Andrews, P.K., and Hinman, H.R. (2001). Sustainability of three apple production systems. Nature 410: 926-930.

Rehber, E., and Tulhan, S. (2002). Prospects and challenges for developing countries in trade and production of organic food and fibers - The case of Turkey. British Food Journal 104: $371-290$.

Rembiałkowska, E. (2007). Review Quality of plant products from organic agriculture. Journal of the Science of Food and Agriculture 87: 2757-2762.

Rundgren, G. (2006). Best practices for organic policy: what developing country governments can do to promote the organic sector. Retrieved $12^{\text {th }}$ of December 2010 from <http://www.un-trade-environment.org/meetings/africa/2006-0605/documents/Additional\%20resources/Paper\%203\%20\%20Best\%20Practices\%20for\%20Organic\%20Policy.pdf> 
Rundlöf, M., Edlund, M., and Smith, H.G. (2010). Organic farming at local and landscape scales benefits plant diversity. Ecography 33: 514-522.

Sanchez, P.A. (2002). Soil fertility and hunger in Africa. Science 295: 2019-2020.

Schmidhuber, J., and Tubiello, F.N. (2008). Global food security under climate change. PNAS 104: 19703-19708.

Scialabba, N. (2000). Factors Influencing Organic Agriculture Policies with a Focus on Developing Countries. FAO: Rome.

Scialabba, N., and Müller-Lindenlauf, M. (2010). Organic agriculture and climate change. Renewable Agriculture and Food Systems 25: 158-169.

Sen, A. (1981). Poverty and Famines - An Essay on Entitlement and Deprivation. Oxford University Press: New York.

Setboonsarng, S. (2006). Organic Agriculture, Poverty Reduction, and the Millennium Development Goals, ADB Institute, Discussion Paper No. 54.

Shaw, D.J. (2007). World Food Security: A History Since 1945. Palgrave Macmillan: New York.

Slight, M., and Christman, C. (2007). Issues Paper: Organic Agriculture and Access to Food. FAO: Rome.

Smith, H.G., Danhardt, J., Lindström, Å., and Rundlöf, M. (2010). Consequences of organic farming and landscape heterogeneity for species richness and abundance of farmland birds. Oecologica 162: 1071-1079.

Smith, L.C., El Obei, A.E., and Jensen, H.H. (2000). The geography and causes of food insecurity in developing countries. Agricultural Economics 22: 199-215.

Spangenberg, J.H. (2007). Biodiversity pressure and the driving forces behind. Ecological Economics 61: 146-158. 
Sperling, D. (2010). Food law, ethics, and food safety regulation: Roles, justifications, and expected limits. Journal of Agricultural and Environmental Ethics 23: 267-278.

Steerenberg, P., Van Amelsvoort, L., Colosio, C., et al., (2008). Toxicological evaluation of the immune function of pesticide workers, a European wide assessment. Human and Experimental Toxicology 27: 701-707.

Stockdale, E.A., Lampkin, N.H., Hovi, M., Keatinge, R. et al. (2001). Agronomic and environmental implications of organic farming systems, Advances in Agronomy 70: 261-262.

Szirmai, A. (2005). Agricultural Development and Rural development. In Szirmai, A. (ed.), The Dynamics of socio-economic development (pp. 355-425). Cambridge University Press: Cambridge.

Taylor, A. (2006). Overview of the Current State of Organic Agriculture in Kenya, Uganda and the United Republic of Tanzania and the Opportunities for Regional Harmonization. UNEP-UNCTAD Capacity Building Task Force on Trade, Environment and Development, Geneva.

Thierfelder, C. and Wall, P.C. (2009). Effects of conservation agriculture techniques on infiltration and soil water content in Zambia and Zimbabwe. Soil and Tillage Research 105: 217-227.

Tilman, D. (1998). The greening of the green revolution. Nature 296: 211-212.

Timmer, C.P. (2000). The macro dimensions of food security: economic growth, equitable distribution, and food price stability. Food Policy 25: 283-295.

UNEP-UNCTAD (2008). Organic Agriculture and food Security in Africa, retrieved $1^{\text {st }}$ of December 2010 from <http://www.unctad.org/en/docs/ditcted200715_en.pdf >

United Nations (1975).Report of the World Food Conference; 1974 November 5-16; Rome, IT. United Nations: Rome. 
USDA (2007). Food Security Assessment 2006. USDA: Washington.

Vaarst, M., Ssekyewa, C., Halberg, N., et al. (2009). Organic Agriculture for Improved Food Security in Africa. Retrieved $19^{\text {th }}$ of December 2010 from http://www.icrofs.org/pdf/2009_ddrn_report_august.pdf

Van Elzakker, E., Parrott, N., Chola Chonya, M., and Adimado, S. (2007). Organic Farming in Africa. In Willer, H., \& M. Yussefi, (eds.) (2007). The World of Organic Agriculture. Statistics and Emerging Trends 2007. 9th edition, totally revised and updated. International Federation of Organic Agriculture Movements IFOAM, Bonn, Germany \& Research Institute of Organic Agriculture FiBL, Frick, Switzerland

Vandecandelaere, E., Arfini, F., Belletti, G., Marescotti, A., et al. (2009). Linking people, places and products - A guide for promoting quality linked to geographical origin and sustainable geographical indications ( $2^{\text {nd }}$ edition), FAO and SINER-GI: Rome.

Vanhaute, E. (2009). From famine to food crisis. What history can teach us about local and global subsistence crises, MPRA Paper No. 17630, Ghent University, Belgium, retrieved $22^{\text {th }}$ of December 2010 from http://mpra.ub.uni-muenchen.de/17630/

Vasilikiotis, C. (2000). Can Organic Farming "Feed the World"? Retrieved $21^{\text {st }}$ of December 2010 from <http://agroeco.org/doc/organic_feed_world.pdf>, University of California, Berkeley: CA.

Weibel, F., Bickel, R., Leuthold, S., and Alfoldi, T. (2000). Are organically grown apples tastier and healthier? A comparative field study using conventional and alternative methods to measure fruit quality. Acta Horticulturae 57: 417-426.

Willer, H., and Kilcher, L. (Eds.) (2009). The World of Organic Agriculture. Statistics and Emerging Trends 2009. FIBL-IFOAM Report. IFOAM, Bonn; FiBL, Frick; ITC, Geneva. 
Willer, H., and Yussefi, M. (2007). The World of Organic Agriculture. Statistics and Emerging Trends 2007. International Federation of Organic Agriculture Movements (IFOAM): Bonn.

Williams, C.M. (2002). Nutritional quality of organic food: shades of grey or shades of green? Proceedings of the Nutrition society 61: 19-24.

Williamson, C.S. (2007). Is organic food better for our health? Nutrition Bulletin 31: 104108.

Winter, C.K. and Davis, S.F. (2006). Organic foods. Journal of Food Science 71: 117-124.

WFP (2010). Our work, retrieved $1^{\text {st }}$ of December 2010 from <http://www.wfp.org/ourwork>

WHO (2010). Food Safety, retrieved $3^{\text {rd }}$ of December 2010 from $<$ http://www.who.int/foodsafety/en/>

Woese, K., Lange, D., Boess, C., and Bogel, K.W. (1997). A comparison of organically and conventionally grown foods-results of a review of the relevant literature. Journal of the Science of Food and Agriculture 74: 281-293.

Woods, D. (2009). Organic and conventional agriculture: A comparison of conventional, manure, and legume systems on soil carbon, soil nitrogen, yield, and economic returns from a long term system in the mid-Atlantic. Retrieved $21^{\text {st }}$ of December 2010 from $<$ http://proquest.umi.com/pqdlink?Ver=1\&Exp=1202015\&FMT=7\&DID=1913664331\&RQT=309\&attempt=1\&cfc $=1>$

Worthington, V., (2001). Nutritional quality of organic versus conventional fruits, vegetables and grains, Journal of Alternative and complementary Medicine 7: 161-173.

Worthington, V. (1998). Effect of agricultural methods on nutritional quality: a comparison of organic with conventional crops. Alternative Therapies in Health and Medicine 4: $58-69$. 
WTO (2009). Statistics Database - Country Profile India. Retrieved $7^{\text {th }}$ of January 2011 from $<$ http://stat.wto.org/CountryProfile/WSDBCountryPFView.aspx?Language=E\&County=IN> Yussefi, M., and Willer, H. (2007). Organic Farming Worldwide 2007: Overview \& Main Statistics. In Willer, H., \& M. Yussefi, (eds.) (2007). The World of Organic Agriculture. Statistics and Emerging Trends 2007. 9th edition, totally revised and updated. International Federation of Organic Agriculture Movements IFOAM, Bonn, Germany \& Research Institute of Organic Agriculture FiBL, Frick, Switzerland

Zhu, Y., Chen, H., Fan, J., et al. (2000). Genetic diversity and disease control in rice. Nature 406: $718-722$. 
Table 1: Main opportunities of OA in fighting undernourishment

\begin{tabular}{|c|c|}
\hline Main potentials & Reference(s) \\
\hline \multicolumn{2}{|l|}{ Access to food } \\
\hline - Poverty reduction & $\begin{array}{l}\text { Oelofse et al., 2010; Thierfelder \& Wall, 2009; Kilcher, 2007; Willer \& } \\
\text { Yussefi, 2007; Setboonsarng, 2006; Kotschi et al., 2003; Parrot \& Van } \\
\text { Elzakker, 2003; Bruinsma, 2003; Parrott \& Marsden, 2002; Bhatta et al., } \\
\text { 2009; UNEP-UNCTAD, 2008; FAO, } 2007\end{array}$ \\
\hline \multicolumn{2}{|l|}{ Sustainable food production } \\
\hline - Climate resilience & $\begin{array}{l}\text { Scialabba \& Müller-Lindenlauf, 2010; Muller \& Davis, 2009; Niggli et al., } \\
\text { 2008; Lee et al., } 2008\end{array}$ \\
\hline - Preventing soil degradation & Niggli et al., 2007; Kaihura et al., 1999 \\
\hline - Drought resistance to drought & $\begin{array}{l}\text { Muller \& Davis, 2009; Thierfelder \& Wall, 2009; Lotter et al., 2003; Ramesh } \\
\text { et al., } 2005\end{array}$ \\
\hline - Water efficiency & $\begin{array}{l}\text { Thierfelder Muller \& Davis, 2009; Thierfelder \& Wall, 2009; Giller et al., } \\
\text { 2003; Lotter et al., } 2003\end{array}$ \\
\hline - Pest resistance & $\begin{array}{l}\text { Meyling et al., 2010; Birkhofer et al., 2008; Letrouneau \& Bothwell, 2008; } \\
\text { Badgley et al., 2007; FAO, 2007; Marinari et al., } 2006\end{array}$ \\
\hline Food utilization & \\
\hline - Food safety & $\begin{array}{l}\text { Azadi \& Ho, 2010; Lairon, 2010; Rembiałkowska, 2007; Carvalho, 2006; } \\
\text { Winter \& Davis, 2006; Lu et al., } 2006\end{array}$ \\
\hline - Food nutrition & Williamson, 2007; Williams, 2002 \\
\hline
\end{tabular}


Table 2: Main challenges of OA in fighting undernourishment in developing countries

\begin{tabular}{ll}
\hline Main potentials & Reference(s)
\end{tabular}

Increasing productivity of OA

Developing domestic markets

Developing research facilities for OA

Stimulating knowledge of OA

Developing institutions supporting OA

Enhancing farmers' access to credits

Developing farmers organizations
Gianessi, 2009; Connor, 2008

Giovannucci, 2006; Pretty et al., 2003

Giovannucci, 2006

Demiryürek et al., 2008; Borron, 2006; Crucefix, 1998; Bravo-Ureta

\& Pinheiro, 1993

Demiryürek et al., 2008; Giovannucci, 2006

FAO, 2007

Slight \& Christman, 2007; Giovannucci, 2006 